\title{
Her-2 Neu Expression in Endometrial Carcinoma
}

\author{
AFAF T. ELNASHAR, M.D.*; NOHA ED. HASSAB ELNABY, M.D.*; ASMAA A. ABDELLATEF, M.D.* and \\ MOHAMED N. SALEM, M.D.** \\ The Departments of Pathology* and Obstetrics \& Gynaecology**, Faculty of Medicine, Sohag University
}

\begin{abstract}
Introduction: Endometrial cancer formed 0.004 of the tumors in Egypt. Detection of high grade tumors from the low-grade ones is mandatory for survival of the patients.

Aim of the Work: The use of immunohistochemical technique to detect the expression of Her-2 neu in endometrial carcinomas.

Material and Methods: Fifty cases of endometrial carcinoma (37 endometrioid, 10 serous, 1 clear cell and 2 undifferentiated carcinomas) were stained with Her-2 neu and its immunoexpression results were evaluated statistically using Chi-square and $t$-test.

Results: Her-2 neu was expressed in (76\%) 38/50 cases with statistically significant relation between Her-2 expression and both grade of the tumor $p<0.013$ and stage $p<0.05$. Although Her-2 immunostaining was not correlated with tumor histological type $p<0.088$.

Conclusions: Her-2 neu could be used to detect the lowgrade, early-stages, endometrial carcinomas from the more aggressive high-grade endometrial carcinomas for therapy modulation.
\end{abstract}

Key Words: Her-2 neu - Endometrial carcinoma - Immunohistochemical expression.

\section{Introduction}

ENDOMETRIAL carcinoma (EC) is the fourth most common cancer in women in the developed world. Classification of ECs by histomorphologic criteria has limited reproducibility and better tools are needed to distinguish these tumors and enable a subtype-specific approach to research and clinical care [1]

High-grade carcinomas of the endometrium (ECs) commonly include serous, clear cell, (FIGO) grade 3 endometrioid and undifferentiated endometrial carcinomas. Diagnostic disagreement between

Correspondence to: Afaf T. Elnashar, The Department of Pathology, Faculty of Medicine, Sohag University pathologists in distinguishing between these tumors is not uncommon owing to overlapping of the morphologic features by routine H\&E stain. Immunohistochemistry is helpful as an objective method for a better diagnostic reproducibility, and a reliable prediction of the clinical outcomes $[2,3]$

Following the successful development of targeted therapy against Her-2 in breast cancer, reports on Her-2 overexpression have sparked considerable interest for a potential novel Her-2-based therapy in endometrial carcinoma (ECs) [4].

The major challenge is in distinguishing the features that comprise low, intermediate, and high risk disease in ECs. Multiple different risk predictive clinical models have been developed to guide treatment $[\mathbf{5 , 6}]$.

Several research teams have defined immunohistochemical and/or mutation profiles to aid in distinguishing ECs subtypes [7]. In one series, a set of seven immunohistochemical markers was able to improve the distinction between high-grade ECs histeotypes [8]. The most comprehensive molecular study of ECs to date has been The Cancer Genome Atlas (TCGA) project, which included a combination of whole genome sequencing, microsatellite instability (MSI) assays, and copy number analysis. Molecular information was used to classify endometrioid and serous endometrial cancers into four groups: POLE ultramutated, microsatellite instability (MSI) hypermutated, copy-number (CN) low, and $\mathrm{CN}$ high that correlate with progressionfree survival [9]. Stelloo et al., 2016 used a combination of TP53 mutational status, MSI status, POLE EDM hotspot mutations. Testing ultimately yielded four molecular subgroups: Group 1- p53 (mutation identified), group 2- MSI, group 3- POLE (POLE EDM identified), and finally group 4- NSMP, a group with (no specific molecular profile [10]. It 
had been demonstrated that women within each molecular subgroup have clinic-pathological characteristic that have consistently been shown to be typical of that group $[\mathbf{1 1 , 1 2}]$. It has been shown that a combination of markers, including p53, p16, PTEN, and PR, may be helpful in discriminating uterine serous from endometrioid carcinoma [13], while most Undifferentiated carcinomas (UCs) showed expression of epithelial membrane antigen (EMA), CK8/18 (CAM 5.2), and approximately $50 \%$ of the tumors showed loss of at least 1 mismatch repair proteins (MMRs). The typical serous carcinoma is strongly and diffusely positive for p53 and p16, whereas these markers are less commonly positive in clear cell carcinoma [14].

Human epidermal growth factor receptor 2 (HER2) is a member of the epidermal growth factor receptor family having tyrosine kinase activity. The HER 2 receptor is a 1255 amino acid, $185 \mathrm{kD}$ transmembrane glycoprotein located at the long arm of human chromosome 17 (17q12) [15] Homo- or heterodimerization results in the autophosphorylation of tyrosine residues within the cytoplasmic domain of the receptors and initiates a variety of signaling pathways, principally the mitogen-activated protein kinase (MAPK), phosphatidylinositol-4,5-bisphosphate 3-kinase (PI3K), and protein kinase $\mathrm{C}(\mathrm{PKC})$ resulting in cell proliferation, survival, differentiation, angiogenesis, and invasion. The introduction of Her-2 directed therapies has dramatically influenced the outcome of patients with Her-2 positive breast and gastric/ gastroesophageal cancers; however, the results have been proved disappointing in other Her-2 overexpressing cancers. Both Her-2 overexpression and amplification have been linked to poor prognosis in endometrial carcinoma [16].

\section{Aim of the work:}

To study Her-2 neu immunoexpression in endometrial carcinomas and its possible role in differentiating low-grade from high-grade endometrial carcinomas for therapeutic purposes.

\section{Material and Methods}

This is a prospective study conducted for a period of 2 years from August 2015 to June 2017, in the Department of Pathology, Sohag University. A total number of 50 cases of endometrial cancers received at the Pathology department were included in the study. All the relevant clinical data were obtained from the patients' medical records. Tissues including hysterectomy and endometrial biopsies were subjected to routine processing and sections were stained with hematoxylin and eosin (H\&E).
The histopathological sections were diagnosed based on WHO classification 2014 [17]. Three-4 micron sections were taken from formalin-fixed, paraffin-embedded tissue blocks for immunohistochemistry. The sections were stained by immunohistochemical technique with Her2 neu (Cat \#MS$730-\mathrm{R} 7(7.0 \mathrm{ml})$ at a dilution of $1 / 100$ for 2 hours at room temperature. Positive control was run with each batch. Positive staining was breast carcinoma sections; the negative control was performed on the same tissue without primary antibody. Her2 neu is a cell membrane marker. Immunohistochemical assessment of Her2 neu overexpression was graded as by ASCO (American society of clinical oncology)/CAP (College of American Pathologists) 2013 guidelines [18]. Data were analyzed statistically using Chi-square and $t$-test using SPSS program [14].

\begin{tabular}{|c|c|c|}
\hline Staining pattern & Score & $\begin{array}{l}\text { Her-2 expression } \\
\text { assessment }\end{array}$ \\
\hline $\begin{array}{l}\text { No staining is observed, or } \\
\text { membrane staining is observed } \\
\text { in }<10 \% \text { of the tumor cells. }\end{array}$ & 0 & Negative \\
\hline $\begin{array}{l}\text { - A faint/barely perceptible mem- } \\
\text { brane staining is detected in } \\
>10 \% \text { of the tumor cells. }\end{array}$ & + & Negative \\
\hline $\begin{array}{l}\text { A weak to moderate complete } \\
\text { membrane staining is observed } \\
\text { in }>10 \% \text { of the tumor cells. }\end{array}$ & ++ & $\begin{array}{l}\text { Weakly positive/ } \\
\text { equivocal }\end{array}$ \\
\hline $\begin{array}{l}\text { A strong complete membrane } \\
\text { staining is observed in }>30 \% \text { of } \\
\text { the tumor cells. }\end{array}$ & +++ & Strongly positive \\
\hline
\end{tabular}

Staging of all the endometrial carcinomas was done according to FIGO (International federation of Gynaecology and Obstetrics) staging [19,20] .

\section{Results}

The age range of the 50 studied patients with different histological types of endometrial carcinoma was (40-80) years, mean age was 59.4 years, and median age was 60 years. The patients' clinical and histopathological data were showed in (Table 1). The studied cases were classified in to 37 cases endometrioid carcinoma (25 grade 1, 11 grade 2 and 1 grade 3 ), 10 cases serous, 1 case clear cell and 2 cases undifferentiated carcinoma (Table 2).

Her-2 neu was positive in $38 / 50(76 \%)$ of all cases of endometrial carcinoma (31 of them were endometrioid, 6 were serous and 1 was undifferentiated) (Tables 2,3, Graph 1). Her-2 neu was expressed in 31/37 (83.8\%) endometrioid carcinomas ( $92.0 \%$ grade I, $82 \%$ grade II, in $0 \%$ grade III), 6 
cases of serous carcinoma and in 1 case of undifferentiated carcinoma. There was a decrease in expression of Her-2 neu with increasing the tumor grade, with a statistically significant difference $p$ - value $<0.013$ (Table 2, Graph 2). We found significant decrease in Her-2 neu expression with increasing stage of the tumor $p$-value 0.05 (Table 3 , Graph 3).

Table (1): Clinical and histopathological data of studied patients $(\mathrm{No}=50)$

\begin{tabular}{|c|c|c|c|c|}
\hline \multirow{2}{*}{ Parameter } & \multicolumn{4}{|c|}{ Histopathological type } \\
\hline & $\begin{array}{l}\text { Endometrioid ca. } \\
\quad(\mathrm{No}=37)\end{array}$ & $\begin{array}{c}\text { Serous } \\
(\mathrm{No}=10)\end{array}$ & $\begin{array}{l}\text { Clear cell } \\
(\mathrm{No}=1)\end{array}$ & $\begin{array}{c}\text { Undifferentiated } \\
(\mathrm{No}=2)\end{array}$ \\
\hline \multicolumn{5}{|l|}{ Age (years): } \\
\hline$<50$ & $6 / 37(16.2 \%)$ & $3 / 10(30 \%)$ & $1 / 1(100 \%)$ & $0 / 2(0 \%)$ \\
\hline$\geq 50$ & $31 / 37(83.8 \%)$ & $7 / 10(70 \%)$ & $0 / 1(0 \%)$ & $2 / 2(100 \%)$ \\
\hline \multicolumn{5}{|l|}{ Clinical presentation: } \\
\hline Post-menopausal bleed & $20 / 37(54.1 \%)$ & $5 / 10(50 \%)$ & $0 / 1(0 \%)$ & $2 / 2(100 \%)$ \\
\hline Peri-menopausal bleed & $3 / 37(1 \%)$ & $3 / 10(30 \%)$ & $1 / 1(100 \%)$ & $0 / 2(0 \%)$ \\
\hline Uterine mass or polyp & $14 / 37(37.8 \%)$ & $2 / 10(120 \%)$ & $0 / 1(0 \%)$ & $0 / 2(0 \%)$ \\
\hline \multicolumn{5}{|l|}{ Tumour size: } \\
\hline$\leq 3 \mathrm{~cm}$ & $9 / 37(24.3 \%)$ & $0 / 10(0 \%)$ & $0 / 1(0 \%)$ & $0 / 2(0 \%)$ \\
\hline$>3 \mathrm{~cm}$ & $26 / 37(70.3 \%)$ & $3 / 10(30 \%)$ & $0 / 1(0 \%)$ & $1 / 2(50 \%)$ \\
\hline D\&C "fragments" & $2 / 37(5.4 \%)$ & $7 / 10(70 \%)$ & $1 / 1(100 \%)$ & $1 / 2(50 \%)$ \\
\hline \multicolumn{5}{|l|}{ Tumour stage: } \\
\hline $0-1-2$ & $37 / 37(100 \%)$ & $0 / 10(0 \%)$ & $0 / 1(0 \%)$ & $1 / 2(50 \%)$ \\
\hline $3-4$ & $0 / 37(0 \%)$ & $10 / 10(100 \%)$ & $1 / 1(100 \%)$ & $1 / 2(50 \%)$ \\
\hline \multicolumn{5}{|l|}{ Lymph node (LN) status: } \\
\hline Negative & $37 / 37(100 \%)$ & $1 / 10(10 \%)$ & & $1 / 2(50 \%)$ \\
\hline Positive & $0 / 37(0 \%)$ & $9 / 10(90 \%)$ & $1 / 1(100 \%)$ & $1 / 2(50 \%)$ \\
\hline
\end{tabular}

Table (2): Grading and histological types of Her-2+ve cases.

\begin{tabular}{|c|c|c|c|c|c|c|}
\hline Histological & No & Grade & Grade & Grad & Her-2 & Her-2 \\
\hline & & & II & III & $+\mathrm{ve}$ & $-\mathrm{ve}$ \\
\hline $\begin{array}{l}\text { Endometrioid } \\
\text { carcinoma }\end{array}$ & 37 & 25 & 11 & 1 & 31 & 6 \\
\hline Serous carcinoma & 10 & - & - & 10 & 6 & 4 \\
\hline Clear cell carcinoma & 1 & - & - & 1 & 0 & 1 \\
\hline $\begin{array}{l}\text { Undifferentiated } \\
\text { carcinoma }\end{array}$ & 2 & - & - & 2 & 1 & 1 \\
\hline Total & 50 & 25 & 11 & 14 & 38 & 12 \\
\hline
\end{tabular}

Table (3): Her-2 neu expression in endometrial carcinoma according to the stage and grade.

\begin{tabular}{|c|c|c|c|c|c|c|c|c|}
\hline & \multicolumn{3}{|c|}{ Tumor grading } & \multicolumn{4}{|c|}{ Tumor stage } & \\
\hline & I & II & III & I & II & III & IV & \\
\hline Her- 2 +ve & 23 & 8 & 7 & 30 & 1 & 3 & 4 & 38 \\
\hline Her-2 -ve & 2 & 3 & 7 & 5 & 2 & 1 & 4 & 12 \\
\hline Total & 25 & 11 & 14 & 35 & 3 & 4 & 8 & 50 \\
\hline$p$-value & & 013 & & & & & & \\
\hline
\end{tabular}

N.B: grade III including high grade endometrioid, serous, clear cell and undifferentiated carcinoma.

Chi square test is used* ${ }^{*}$ significant.

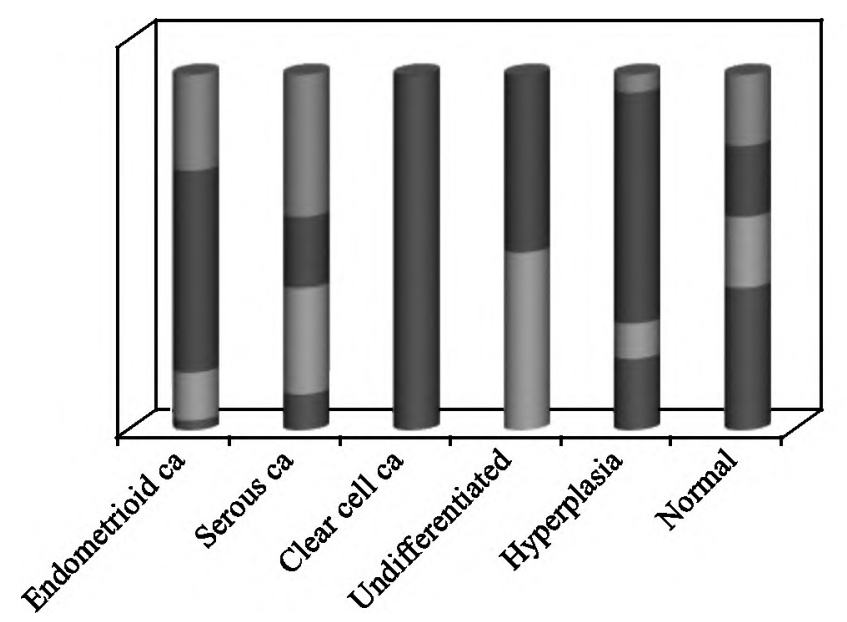

Her-2 neu immunostaining
scoring +++
Her- 2 neu immunostaining
scoring ++
Her-2 neu immunostaining
scoring +
Her-2 neu immunostaining
scoring 0

Graph (1): Her-2 scoring in relation to tumor type in the studied cases. 


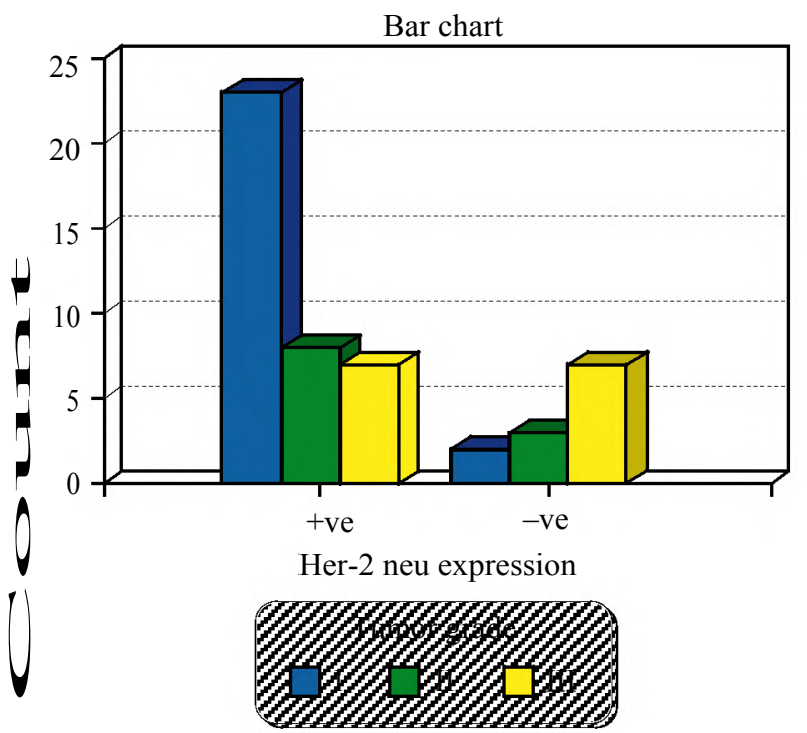

$\downarrow$ Graph (2): Her-2 expression in relation to tumor grade.$$
1
$$

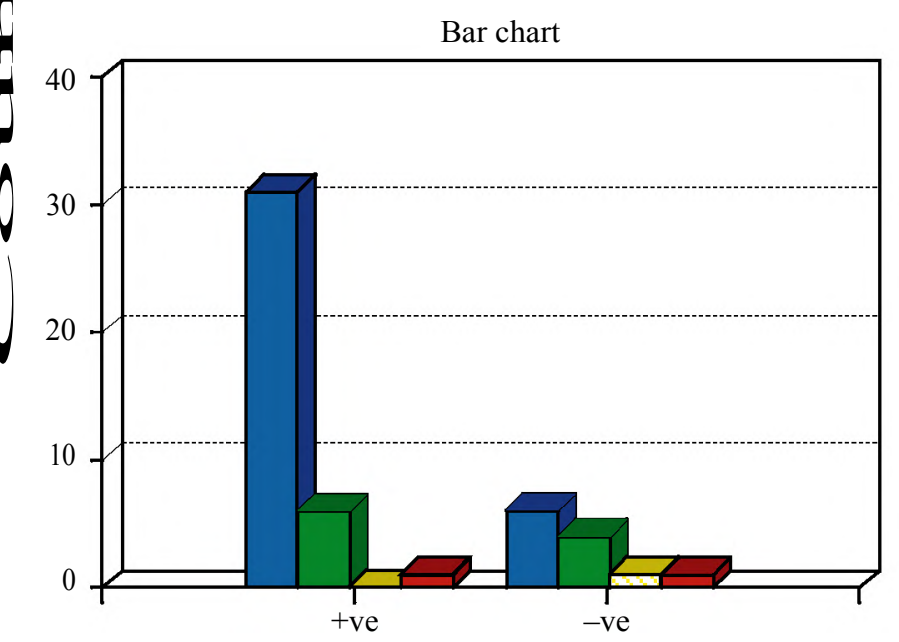

Her-2 neu expression

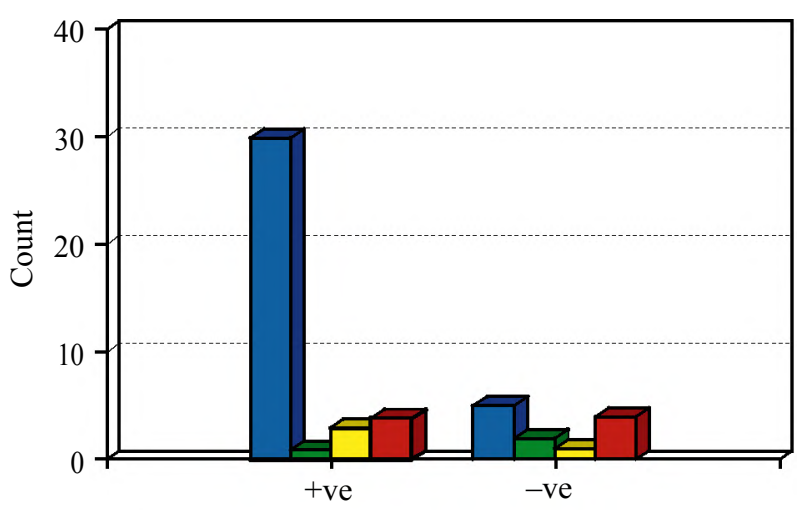

Her-2 neu expression

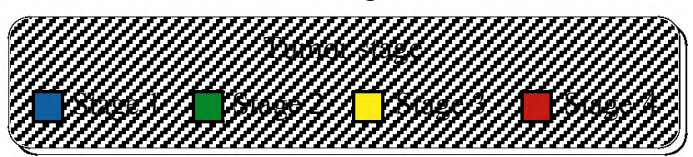

Graph (3): Her-2 expression in relation to tumor stage.

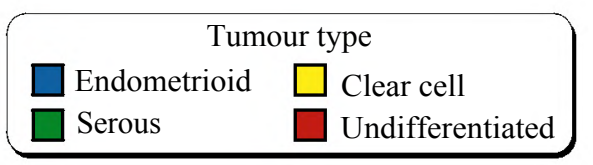

Graph (4): Her-2 expression in relation to tumour type.
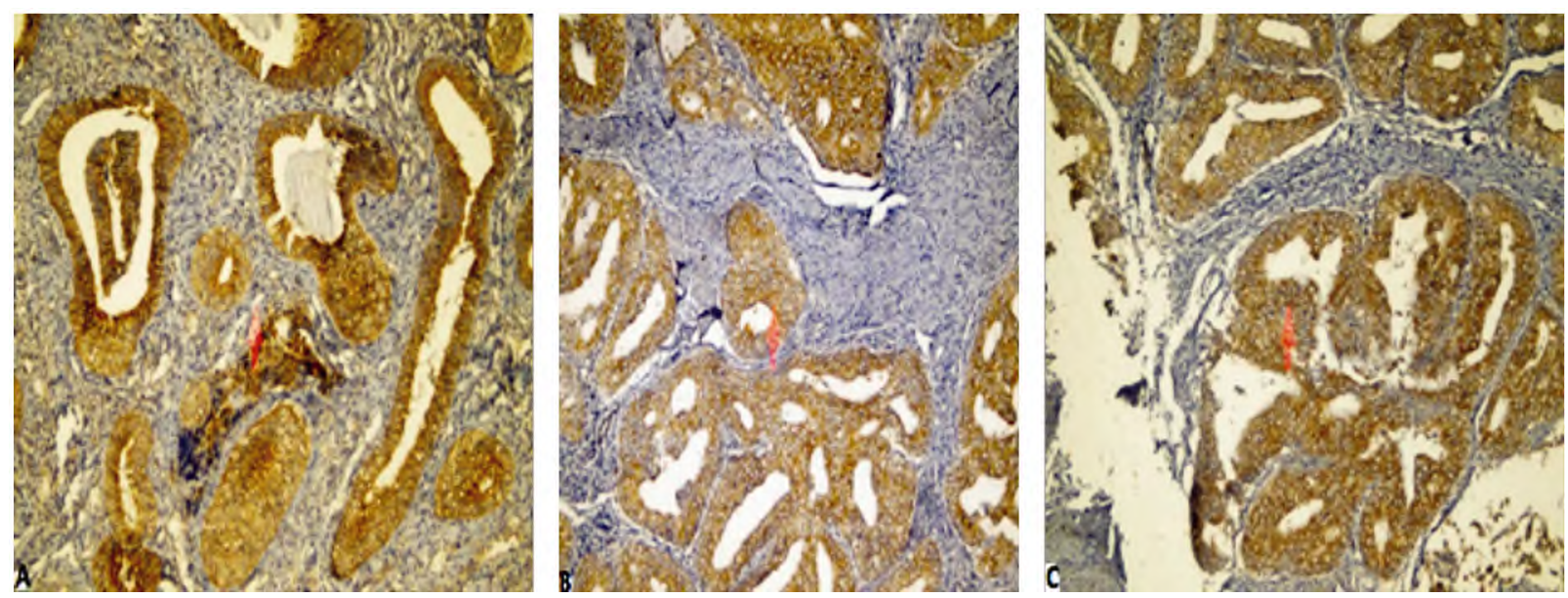

Fig. (1): Her-2 expression in simple endometrial hyperplasia (A, B\&C: X 100). 

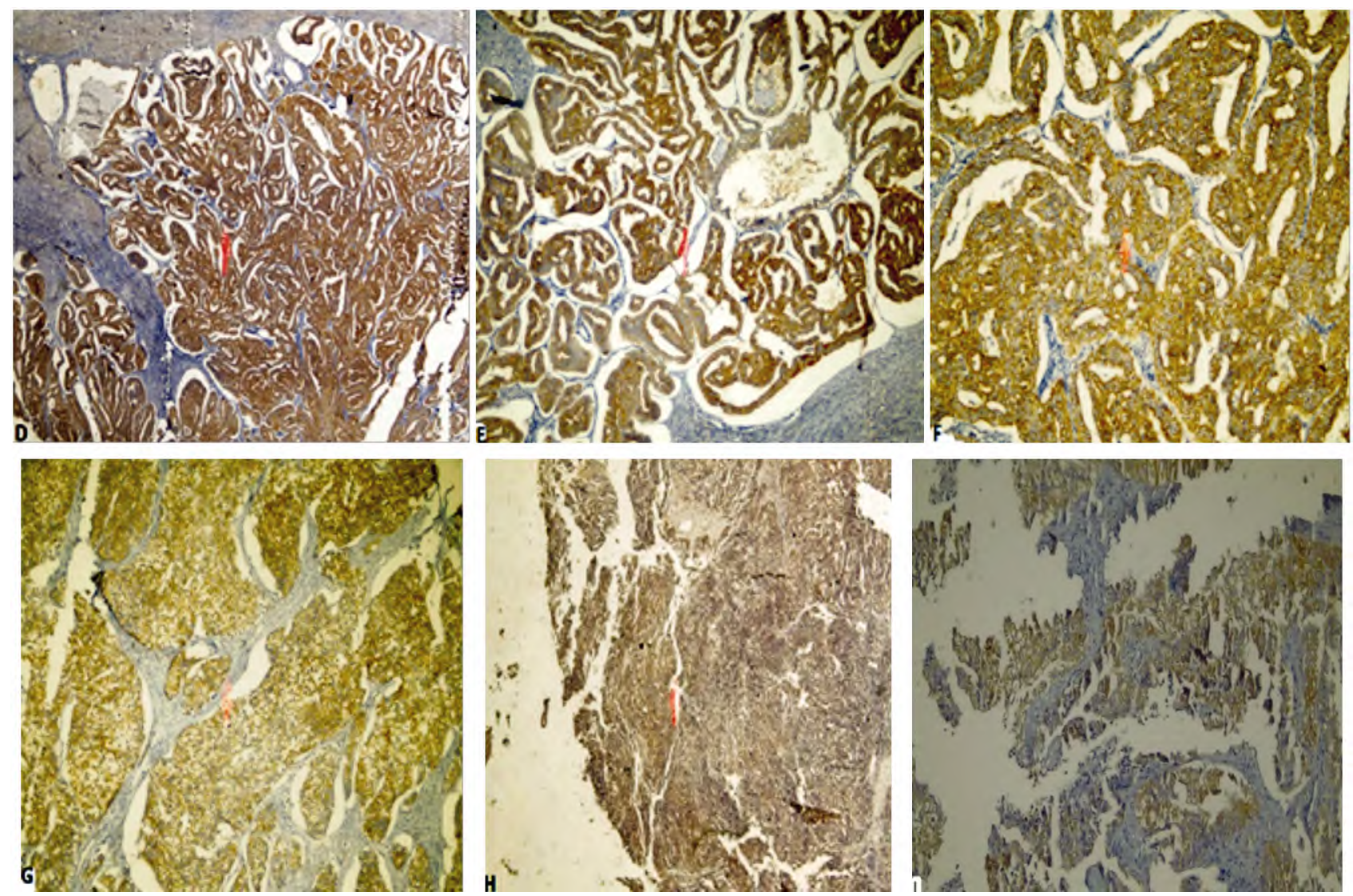

Fig. (1): D: Her-2 immunostaining in endometrioid carcinoma grade I (D: X 40, E: X 100, F: X 200).

G: Her-2 immunostaining in endometrioid carcinoma Grade III (X 100).

H: Her-2 expression in undifferentiated carcinoma (X 40).

I: Her-2 expression in papillary serous carcinoma (X 40).

\section{Discussion}

Endometrial carcinoma is the fifth most common cancer of women worldwide [21]. In Egypt, $426 / 100000$ population had uterine cancer at 2014 that will increase to $502 / 100000$ population at 2020 [22].

Her-2 overexpression has been shown to play a key role in the pathogenesis of various different cancer types, including breast, ovarian, gastric, and esophageal carcinomas [23].

Human epidermal growth factor receptor 2 (Her-2) is a member of the epidermal growth factor receptor family having tyrosine kinase activity. Dimerization of the receptor results in the autophosphorylation of tyrosine residues within the cytoplasmic domain of the receptors and initiates a variety of signaling pathways leading to cell proliferation and tumorigenesis. Her-2 is expressed in many tissues and its major role in these tissues is to facilitate excessive/uncontrolled cell growth and tumorigenesis $[23,25]$.
In our study Her- 2 neu was expressed in $38 / 50$ cases of endometrial carcinomas $(76 \%)$ with a statistically significant relation between Her-2 immuno-expression and grade of the tumor (increased intensity of the expression with low grade than with high grade tumors) $(p<0.013)$. Although the clinical and therapeutic importance of Her-2 in endometrioid type endometrial carcinomas may not be as high as in uterine serous carcinoma, it may have a prognostic value and potential role in the therapy of advanced and/or high-grade endometrioid carcinomas. Her-2 overexpression and amplification in endometrioid carcinomas have been reported in the range of $1 \%$ to $47 \%$ [26]. Direct correlation between tumor grade and Her-2 overexpression/amplification has been observed in some studies $[27,28]$ whereas others have not confirmed such an association [29].

In the current study, Her-2 was expressed in low-grade tumors $63 \%$ and in $37 \%$ of the high grade tumors with a statistically significant relation $(p<0.013)$. Growdon et al., 2015 studied the ex- 
pression of Her- 2 on 86 high-grade endometrial carcinomas and they identified high Her-2 expression in $59 \%$ of the tumors. They mentioned that high-grade endometrial carcinomas expressed higher levels of p95Her-2 (a mutant variant of Her$2 /$ neu) possibly providing rationale for the trastuzumab resistance observed in endometrial carcinoma [30]. Benevolo et al., 2007 found Her-2 to be expressed in $31.5 \%$ of the study cases (200 cases) with the highest rate of expression in papillary carcinoma [31]

In contrast to our results, Srijaipracharoen et al., found that Her-2 neu expression was identified in only $2.8 \%$ of 108 studied cases. They found that all three cases which expressed Her-2 neu were of the endometrioid type [32], while another study of Suthipinthawong et al., reported that Her-2 neu was expressed in only $1.5 \%$ of the studied cases with no statistically significant relation to survival time [33]. Both studies showed low Her-2 immunostaining in endometrial carcinoma and this could be explained by a racial and ethical background of the Asian population.

Coronado et al., 2001 have reported Her-2 neu expression rate of $17 \%$ of 114 cases and its expression had a limited significance on survival [34], similarly, Jongen et al., in a large cohort of 315 endometrioid endometrial carcinomas, concluded that there was no significant correlation between Her-2 neu overexpression and patients' survival [35], which was also the finding of Engelsen et al., in a cohort consisting of similarly large sample of endometrioid cases (316 cases) where Her-2 was expressed in $23 \%$ of the cases [36] . Gul et al., detected a positive staining with Her-2 in $18.1 \%$ of the 72 casess of endometrial adenocarcinomas. They didn't find a statistically significant difference between Her-2 and histological grade, myometrial invasion, lymph node status, stage and survival [37].

In the present study Her-2 was expressed in $83 \%$ (3 $1 / 38$ cases) at stages I \& II and in $7 / 38$ cases at stages III\& IV with a statistically significant relation $p<0.05$. Kalogiannidis et al., 2014, Her2 neu expression was detected in 14 of 77 cases $(18.2 \%)$ and rate was significantly increased in patients with high FIGO stage $(p<0.001)$ and tumor diameter $>2 \mathrm{~cm}(p<0.04)[38]$

Grushko et al., 2008 had examined prospectively collected tumors from women with stage III-IV endometrial cancer, and identified Her-2 overexpression in $44 \%$ of the cases by IHC with increased positivity seen in the serous subtype [28]. Morrison et al., concluded in their study that the expression of Her-2 was significantly correlated with higher grade $(p<.0001)$ and stage $(p<.0001)$, non endometrioid histology type $(p<.0001)$, positive lymph node status $(p<.0107)$, and greater than $50 \%$ myometrial invasion $(p<.0002)$ [27]. These conflicting results could be explained by the smaller number of cases in our study (50 cases) in comparison to the Morrison study which is considered the largest study to date including 484 cases with Her-2 overexpression/amplification detection using both immunohistochemistry and fluorescent in situ hybridization techniques.

\section{Conclusions:}

Her-2 is an important factor particularly in lowrisk tumors. Unfortunately the role that Her-2 plays in the vast majority of endometrial cancer may be diminished in comparison with breast cancer due to the relatively low incidence of expression in high-grade and stage endometrial cancer.

\section{References}

1- TALHOUK A. and MCALPINE J.N.: New classification of endometrial cancers: The development and potential applications of genomic-based classification in research and clinical care. Gynecologic Oncology Research and Practice., 3: 14, 2016.

2- GILKS C.B., OLIVA E. and SOSLOW R.: Poor interobserver reproducibility in the diagnosis of high-grade endometrial carcinoma. Am. J. Surg. Pathol., 37 (6): 874 881,2013

3- SOSLOW R.: High-grade endometrial carcinomas: Strategies for typing. Histopathology, 62 (1): 89-110, 2013.

4- BUZA N., ROQUE D.M. and SANTIN AD.: HER2/neu in Endometrial Cancer: A Promising therapeutic target with diagnostic challenges. Arch. Pathol. Lab. Med., 138: 343-350, 2014.

5- COLOMBO N., CREUTZBERG C., AMANT F., BOSSE T., GONZÁLEZ-MARTÍN A., LEDERMANN J., MARTH C., NOUT R., QUERLEU D., MIRZA M.R. and SESSA C.: ESMO-ESGO-ESTRO Endometrial Consensus Conference Working Group. ESMO-ESGO-ESTRO Consensus Conference on Endometrial Cancer: Diagnosis, treatment and follow-up Ann. Oncol., 27 (1): 16-41, 2016.

6- IMAI K., KATO H., KATAYAMA K., NAKANISHI K., KAWANO A., IURA A., KONNAI K., ONOSE R., HIRAHARA F. and MIYAGI E.: A preoperative risk-scoring system to predict lymph node metastasis in endometrial cancer and stratify patients for lymphadenectomy. Gynecol. Oncol., 142 (2): 273-7, 2016.

7- HOANG L.N., LEE Y.S., KARNEZIS A.N., TESSIERCLOUTIER B., ALMANDANI N., COATHAM M., GILKS C.B., SOSLOW R.A., STEWART C.J., KÖBEL M. and LEE C.H.: Immunophenotypic features of dedifferentiated endometrial carcinoma-insights from BRG1/INI1-deficient tumours. Histopathology, 69 (4): 560-9, 2016. 
8- ALKUSHI A., KOBEL M., KALLOGER S.E. and GILKS C.B.: High-grade endometrial carcinoma: Serous and grade 3 endometrioid carcinomas have different immunophenotypes and outcomes. Int. J. Gynecol. Pathol., 29 (4): 343-350, 2010.

9- KANDOTH C., SCHULTZ N., CHERNIACK A.D., AKBANI R., LIU Y., SHEN H., et al.: Cancer Genome Atlas Research Network, Integrated genomic characterization of endometrial carcinoma. Nature. May 2, 497 (7447): 67-73, 2013.

10- STELLOO E., NOUT R.A., OSSE EM, JÜRGENLIEMKSCHULZ I.J., JOBSEN J.J., et al.: Improved Risk Assessment by Integrating Molecular and Clinicopathological Factors in Early-stage Endometrial Cancer: Combined Analysis of the PORTEC Cohorts. Clin. Cancer Res., 22 (16): 4215-24, 2016.

11- KWON J.S., QIU F., SASKIN R. and CAREY M.S.: Are uterine risk factors more important than nodal status in predicting survival in endometrial cancer? Obstet. Gynecol., 114 (4): 736-43, 2009.

12-TALHOUK A., MCCONECHY M.K., LEUNG S., YANG W., LUM A., SENZ J., BOYD N., et al.: Confirmation of ProMisE: A simple, genomics-based clinical classifier for endometrial cancer. Cancer, Mar 1. 123 (5): 802-813, 2017.

13-ALKUSHI A., KOBEL M., KALLOGER S.E. and GILKS C.B.: High-grade endometrial carcinoma: Serous and grade 3 endometrioid carcinomas have different immunophenotypes and outcomes. Int. J. Gynecol. Pathol., 29 (4): 343-50, 2010.

14- DELAIR D. and SOSLOW R.A. : Endometrial clear cell carcinomas with and without aberrant $\mathrm{p} 53$ expression: A study of 16 cases. Lab. Invest., 92: 265A-266A, 2012.

15- MÉNARD S., PUPA S.M., CAMPIGLIO M., and TAGLIABUE E.: Biologic and therapeutic role of HER2 in cancer. Oncogene., 22 (43): 6570-6578, 2003.

16- IQBAL N. and IQBAL N.: Human Epidermal Growth Factor Receptor 2 (HER2) in Cancers: Overexpression and Therapeutic Implications. Molecular Biology International, 852748-9, 2014.

17- WHO, Pathology and Genetics of Tumours of the Breast and Female Genital Organs IARC Press, 2014.

18- IQBAL B.M. and BUCH A.: Hormone receptors (ER, PR, HER2-neu) status and proliferation index marker (Ki 67) in breast cancer: Their onco-pathological correlation, shortcoming and future trends. Medical. J. of D. Y. Patil. University, 9 (6): 674-9, 2016.

19- PECORELLI S.: Revised FIGO staging for carcinoma of the vulva, cervix and endometrium. Int. J. Gynaecol. Obstet., 105 (2): 103-4, 2009.

20- MUTCH D.G.: The new FIGO staging system for cancer of the vulva, cervix, endometrium and sarcomas. Gynaeco. Oncol., 115: 325-328, 2009.

21- TANTBIROJN P., TRIRATANACHAT S., TRIVIJITSILP P. and NIRUTHISARD S.: Detection of PTEN immunoreactivity in endometrial hyperplasia and adenocarcinoma. J. Med. Assoc. Thai., 91 (8): 1161-1166, 2008.

22- IBRAHIM A.S., KHALED H.M., MIKHAIL N.N.H., BARAKA H. and KAMEL H.: Cancer incidence in Egypt:
Results of National population-based cancer registry program, 437971: 18, 2014.

23- KUNZ P.L., MOJTAHED A., FISHER G.A., FORD J.M., CHANG D.T., BALISE R.R., BANGS C.D., CHERRY A.M. and PAI R.K.: HER2 expression in gastric and gastroesophageal junction adenocarcinoma in a US population: Clinicopathologic analysis with proposed approach to HER2 assessment. Appl Immunohistochem Mol. Morphol., 20 (1): 13-24, 2012.

24- NEVE R.M., LANE H.A., and HYNES N.E.: The role of overexpressed HER2 in transformation. Annals of Oncology, 12 (1): S9-S13, 2001.

25- OLAYIOYE M.A.: Update on HER-2 as a target for cancer therapy: Intracellular signaling pathways of ErbB2/HER-2 and family members. Breast Cancer Research, 3 (6): 385-389, 2001.

26- XU M., SCHWARTZ P., RUTHERFORD T. , AZODI M., SANTIN A., SILASI D., MARTEL M. and HUI P.: HER2/neu receptor gene status in endometrial carcinomas: A tissue microarray study. Histopathology, 56 (2): 269-73, 2010.

27- MORRISON C., ZANAGNOLO V., RAMIREZ N., COHN D.E., KELBICK N., COPELAND L., et al.: HER-2 Is an Independent Prognostic Factor in Endometrial Cancer: Association With Outcome in a Large Cohort of Surgically Staged Patients. J. Clin. Oncol., 24 (15): 2376-2385, 2006.

28- GRUSHKO T.A.1, FILIACI V.L., MUNDT A.J., RIDDERSTRÅLE K., OLOPADE O.I. and FLEMING G.F.: Gynecologic Oncology Group. An exploratory analysis of HER-2 amplification and overexpression in advanced endometrial carcinoma: A Gynecologic Oncology Group study. Gynecol. Oncol., 108 (1): 3-9, 2008.

29- GUL A.E., KESER S.H., BARISIK N.O., KANDEMIR N.O., CAKIR C., SENSU S. and KARADAYI N.: The relationship of c-erbB-2 expression with estrogen receptor and progesterone receptor and prognostic parameters in endometrial carcinomas. Diagn. Pathol., 5: 13, 2010.

30- GROWDON W.B., GROENEWEG J., BYRON V., DIGLORIA C., BORGER D.R., TAMBOURET R., et al.: HER2 over-expressing high grade endometrial cancer expresses high levels of p95HER2 variant. Gynecol. Oncol., 137 (1): 160-6, 2015.

31- BENEVOLO M., VOCATURO A., NOVELLI F., MARIANI L., VOCATURO G., et al.: Prognostic value of HER2 and progesterone receptor expression in endometrial carcinoma with positive peritoneal washing. Anticancer. Res., 27 (4C): 2839-44, 2007.

32- SRIJAIPRACHAROEN S., TANGJITGAMOL S., TANVANICCH S., MANUSIRIVITHAYA S., KHUNNARONG J., et al.: Expression of ER, PR, and Her-2/neu in endometrial cancer: A clinicopathological study. Asian Pacific J. of Cancer Prevention, 11: 215-220, 2010.

33- SUTHIPINTAWONG C., WEJARANAYANG C. and VIPUPINYO C.: Prognostic significance or ER, PR, KI 67, c-erbB2 and P53 in endometrial carcinoma. J. Med. Assoc. Thai., 91: 1779-85, 2008.

34- CORONADO P.J., VIDART J.A., LOPEZ-ASENJO J.A., FASERO M., FURIOBACETE V. and MAGRINA J.: Escudero M P53 overexpression predicts endometrial carcinoma recurrence better than HER-2/neu overexpres- 
sion. Eur. J. Obstet. Gynecol. Reprod Biol., 98: 103-108, 2001.

35- JONGEN V.H., BRIET J.M., DE JONG R.A., JOPPE E., TEN HOOR K.A., BOEZEN H.M., et al.: Nijman HW aromatase, cyclooxygenase 2, HER-2/neu, and p53 as prognostic factors in endometrioid endometrial cancer. Int. J. Gynecol. Cancer, 19: 670-676, 2009.

36- ENGELSEN I.B., STEFANSSON I.M., BEROUKHIM R., SELLERS W.R., MEYERSON M., AKSLEN L.A. and SALVESEN H.B.: HER-2/neu expression is associated with high tumor cell proliferation and aggressive pheno- type in a population based patient series of endometrial carcinomas. Int. J. Oncol., 32: 307-316, 2008.

37- GUL A.E., KESER S.H., BARISIK N.O., KANDEMIR N.O., CAKIR C., SENSU S. and KARADAYI N.: The relationship of cerbB2 expression with estrogen receptor and progesterone receptor and prognostic parameters in endometrial carcinomas. Diagn. Pathol., 5: B, 2010.

38- KALOGIANNIDIS I., PETOUSIS S., BOB OS M., MARGIOULA-SIARKOU C., TOPALIDOU M., et al.: HER$2 /$ neu is an independent prognostic factor in type I endometrial adenocarcinoma. Arch. Gynecol. Obstet., 290: 1231-1237, 2014.

\section{تعبير هير Y نيو فى سرطان بطانة الرحم}

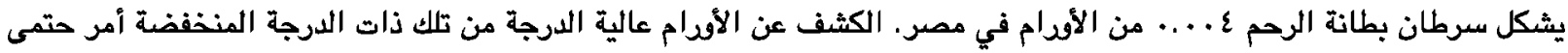

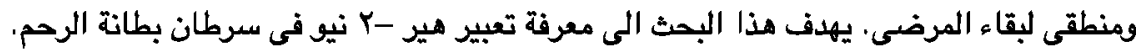

الطريقة: لدرسنا تعبير هير-r نيو عن طريق الصباغة المناعية الهستوكيميائية ل •0 حالة من سرطان بطانة الرحم (rV) عينة سرطان

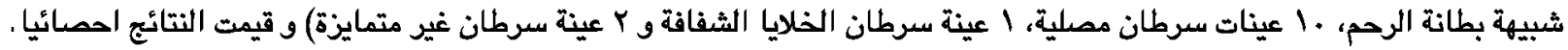

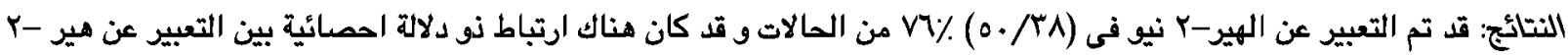



الخلاصدة: يمكن أن يستخدم هير -Y نيو للكثف عن الأقرام ذات الدرجة المنففضة، و ايضا المراحل المبكرة، و تميزيزها من سرطان

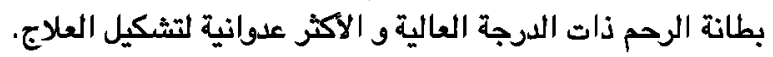

